J. Clin. Chem. Clin. Biochem.

Vol. 16, 1978, pp. 231-234

\title{
Procedure for a Normalised Thyroxine Determination in Small Sephadex Columns
}

\author{
By W. Th. Goedemans
}

Cyclotron and Isotope Laboratories, Petten, The Netherlands,

and

P. C. Bartels

Clinical Chemistry Laboratory, M.C.A. St. Elisabethziekenhuis, Alkmaar, The Netherlands

(Received July $14 /$ October 13,1977 )

Summary: A rapid simple test for measuring normalised serum thyroxine is described in detail, using small Sephadex columns. A small portion of test serum is reintroduced into the test system at the competitive binding stage, so that corrected $\mathrm{T}_{4}$ values are obtained when the concentrations of thyroxine binding globulin are variable. Only $125 \mu \mathrm{l}$ serum is required for the whole test.

Values obtained by the present method correlated well with the product of thyroxine concentration and radioactive $\mathrm{T}_{3}$ uptake $\left(\mathrm{T}_{4}-\mathrm{RT}_{3} \mathrm{U}\right.$ index) and with a commercially available method for normalized thyroxine $\left(\mathrm{T}_{4} \mathrm{~N}\right)$. Day-to-day variation was $\mathrm{CV}=6 \%$.

\section{Verfahren für die Bestimmung des normalisierten Thyroxins in kleinen Sephadex-Säulen}

Zusammenfassung: Ein schneller, einfacher Test für die Messung des normalisierten Thyroxins im Serum mit kleinen Sephadex-Säulen wird im Detail beschrieben. In Fällen abweichender Konzentrationen an Thyroxin-bindendem Globulin werden korrigierte Thyroxinwerte erhalten, wenn eine kleine Portion von Patientenserum während der kompetitiven Bindung nochmals in das Testsystem gegeben wird. Für den gesamten Test werden nur $125 \mu \mathrm{l} \mathrm{Serum}$ benötigt.

Die mit der vorgestellten Methode erhaltenen Werte korrelieren gut mit dem Produkt aus Thyroxin-Gesamtkonzentration und Aufnahme von radioaktivem Trijodthyronin $\left(\mathrm{T}_{4}-\mathrm{RT}_{3} \mathrm{U}-\mathrm{Index}\right)$ und den Werten eines kommerziell erhältlichen Verfahrens für normalisiertes Thyroxin $\left(T_{4} N\right)$. Der Variationskoeffizient von Tag zu Tag beträgt $6 \%$.

\section{Introduction}

It is generally agreed that the concentration of free thyroxine in serum is the most useful clinical test in assessing thyroid function, since the free hormone available to the peripheral tissues is responsible for the hormonal action (1). The quantity of thyroxine binding globulin to which thyroxine is almost entirely bound, is altered in many clinical states. An increase is related to excess estrogens in pregnancy or in women receiving oral contraceptives and a decrease máy arise from andro: genic anabolic steroids (2).

Due to alterations in thyroxine binding blobulin concentration, total thyroxine estimation $\left(T_{4} \mathrm{D}\right)$ and radioactive
$\mathrm{T}_{3}$ uptake $\left(\mathrm{RT}_{3} \mathrm{U}\right)$ may lead to an incorrect diagnosis of hyper- or hypothyroidism. However, determination of the free thyroxine fraction (i.e. the proportion of total thyroxine present in the free form) is tedious and too complex for routine clinical use. An indirect measurement of free thyroxine in the serum is given by the product of thyroxine concentration and $T_{3}$ uptake, the $T_{4}-R_{3} U$ index, which tends to reflect the thyroid status unaltered by changes of thyroxine binding globulin concentration.

Another approach is the assessment of thyroid function using a normalised thyroxine assay: $\mathrm{T}_{4} \mathrm{~N}(3)$. This procedure involves a modification of the determination of total thyroxine. To the initial serum sample is added 
another smaller sample of the same serum, together with the binding globulin present in the second serum sample to contribute in the competitive protein binding of thyroxine. By adding the second portion of serum sample, the revised thyroxine determination becomes more a reflection of the minute amount of free thyroxine present. This is more closely related to the actual thyroid status of the patient than the total thyroxine concentration.

The purpose of the normalised thyroxine or $\mathrm{T}_{4} \mathrm{~N}$ determination is to provide the same information as the combination of total thyroxine and $\left.\mathrm{T}_{3}{ }^{1}\right)$ uptake $\left(\mathrm{RT}_{3} \mathrm{U}\right.$ ratio) (4).

This communication presents a modification of the $T_{4} \mathrm{~N}$ procedure in small Sephadex columns. The main advantage of our method in comparison to a previous method is that only $0.125 \mathrm{ml}$ serum is required for test instead of $0.32 \mathrm{ml}$ in the method of Abreau et al (1), thus the present test is easily applied to very young children.

The principles of the test can be described as follows:

- thyroxine is separated from the serum by pipetting onto a strong alkaline Sephadex column

- the liberated thyroxine, along with the added [ $\left.{ }^{125} \mathrm{I}\right]$ thyroxine tracer in the alkaline medium, is bound by the Sephadex

- the column is washed with $75 \mathrm{mmol} / \mathrm{l}$ barbital buffer to shift the $\mathrm{pH}$ of the column to 8.6 and to wash out any free ${ }^{125} \mathrm{I}$ and the serum proteins (and possible interfering substances such as non-esterified fatty acids) which are now virtually free of thyroxine

- as eluting reagent thyroxine binding globulin solution together with a second aliquot of $25 \mu$ l the patient's serum is added

- equilibrium is established between the Sephadex column and the proteins of the eluting reagent

- the thyroxine bound to the eluting reagent is removed from the Sephadex column by washing with buffer at $\mathrm{pH} 8.6$

- the percentage radioactivity retained by the column is determined

The nature of thyroxine binding to Sephadex is unknown (7), but the hormone is accessible for interaction with $\mathrm{T}_{4}{ }^{1}$ ) antibody, which is excluded from the fluid inside the gel particles. Thyroxine is more firmly bound by thyroxine binding globulin than by Sephadex.

The new method is compared with the combination of total thyroxine and $T_{3}$ uptake expressed as the $T_{4}-R T_{3} U$ index and with a commercially available normalised thyroxine assay ("Quantisorb"; Abbott Laboratories, North Chicago, Ill. 60064), a procedure in which thyroxine is displaced from proteins by acid hydrolysis. Proteins are not discarded; after adjustment of the $\mathrm{pH}$ by addition of barbital buffer, competition takes place

\footnotetext{
1) $T_{3}=$ triiodothyronine, $T_{4}=$ thyroxine
}

with a fixed amount of thyroxine binding globulin. Resin sponges are used to separate the free and protein-bound moieties.

In a forthcoming paper (8) the estimation of $\mathrm{T}_{4} \mathrm{~N}$, using goat thyroxine antibody, will be reported.

\section{Experimental}

Materials and reagents

Sephadex G25 columns

Disposable Sephadex G25 columns (Cyclotron and Isotope Laboratories, 1755 ZG Petten, Holland), $18 \mathrm{~mm}$ long and $12 \mathrm{~mm}$ inner diameter, with a bed volume of $2 \mathrm{ml}$ were used.

Sephadex was swollen in $0.1 \mathrm{~mol} / 1 \mathrm{NaOH}$ for the estimation of thyroxine or normalised thyroxine, and in $75 \mathrm{mmol} / 1 \mathrm{barbital}$ buffer, $\mathrm{pH} 8.6$ for the estimation of $\mathrm{T}_{3}$ uptake.

Barbital buffer, $75 \mathrm{mmol} / 1 \mathrm{pH} 8.6$

Dissolve $15.45 \mathrm{~g}$ of $5,5^{\prime}$-diethyl-barbituric acid sodium salt in about $800 \mathrm{ml}$ of distilled water. Adjust the pH to 8.6 with $0.2 \mathrm{~mol} / \mathrm{liter}$ hydrochloric acid and dilute to $1000 \mathrm{ml}$ with distilled water.

${ }^{125}$ I labelled triiodothyronine and thyroxine

$\left[{ }^{125} \mathrm{I}\right] \mathrm{T}_{3}$ and [ $\left.{ }^{125} \mathrm{I}\right] \mathrm{T}_{4}$, used in a specific activity of $2.22 \mathrm{MBq} /$ $\mu \mathrm{g}$, were obtained from Philips-Duphar B.V., Cyclotron and Isotope Laboratories, 1755 ZG Petten, Holland.

\section{Standard thyroxine solution}

A serum standard was prepared by adding a known amount of pure $\mathrm{Na}-\mathrm{T}_{4} \cdot 5 \mathrm{H}_{2} \mathrm{O}$ (Henning, Berlin) to calf serum, taking into account its residual concentration.

\section{Thyroxine binding globulin solution}

Membrane-filtered calf serum was diluted $1: 10$ in water with $15.4 \mathrm{mmol} / 1 \mathrm{Na}$-azide as preservative. If stored at $4^{\circ} \mathrm{C}$, this thyroxine binding solution remains sțable for more than a year.

Așsaỳs

$T_{4} D$

Total thyroxine concentrations in sera $\left(\mathrm{T}_{4} \mathrm{D}\right)$ were measured in Sephadex columns according to the method of Braverman et al (5).

\section{$R T_{3} U\left(T_{3}\right.$ uptake)}

The $\mathrm{RT}_{3} \mathrm{U}$ ratio (4) in human sera was measured using small Sephadex columns swollen in bärbital buffer as follows:

$\left.0.5 \mathrm{ml}^{125}{ }^{12}\right]_{\mathrm{T}} \mathrm{T}_{3}(3.7 \mathrm{kBq})$ was pipetted onto a Sephadex column, then $50 \mu \mathrm{l}$ of patient's serum was added. After mixing and draining, the column was eluted with $2 \mathrm{ml}$ distilled water. The activity of a column in which standard serum (pooled human serum of at least 300 individuals) was treated in the same way. The $\mathrm{RT}_{3} \mathrm{U}$ ratio was calculated in the following way: $\mathrm{RT}_{3} \mathrm{U}$ ratio $=\frac{\mathrm{P}}{\mathrm{S}}$

in which $\mathrm{P}=$ number of counts of the patient's serum $S=$ number of counts of the standard serum

$T_{4}-R T_{3} U$ index

The $T_{4}-R T_{3} U$ index was defined as: $T_{4}(D) \times R T_{3} U$ ratio (4).

\section{$\mathrm{T}_{4} \mathrm{~N}$ test procedure}

The test conditions were chosen so that the contribution of the second serum sample to the total binding capacity of the eluting mixture containing thyroxine binding globulin, was approximately one third (1). 
The determination of the normalised thyroxine $\left(T_{4} N\right)$ or effective thyroxine ratio (ETR) (6) by the Sephadex column method was carried out at room temperature as follows:

$0.5 \mathrm{ml}$ containing $3.7 \mathrm{kBq} \mathrm{l}{ }^{12 \mathrm{I}_{\mathrm{IJT}}} \mathrm{T}_{4}$ was pipetted onto a column containing Sephadex G25 swollen in $0.1 \mathrm{~mol} / 1 \mathrm{NaOH}$. After pipetting a $0.1 \mathrm{ml}$ serum sample the thyroxine was liberated from the serum proteins by $\mathrm{NaOH}$. After buffering the Sephadex column by treating it with $4 \mathrm{ml} 75 \mathrm{mmol} / \mathrm{l}$ barbital $\mathrm{pH} 8.6$ and adding $0.5 \mathrm{ml}$ eluting solution containing thyroxine binding globulin, the second serum sample $(25 \mu \mathrm{l})$ was applied.

After two minutes incubation on the column, elution of the Sephadex with $4 \mathrm{ml}$ barbital buffer effects a separation of freeand bound thyroxine. This step was followed by measurement of the radioactivity of the columns (free thyroxine).

The count rate of each test serum was compared with a calibration graph produced from duplicate tests using $100 \mu \mathrm{l}$ of standard serum, containing $129 \mathrm{nmol} / \mathrm{l}$ thyroxine. No second serum additions were made. This standard point was defined as corresponding to 20 normalised thyroxine units and extrapolated to the origin by a straight line. The serum test results were read from the derived calibration line.

The definition of normalised units was chosen so that the $\mathrm{T}_{4} \mathrm{~N}$ value of a human pool serum corresponded to the $T_{4}$ content expressed in $\mu \mathrm{g} / \mathrm{dl}$ and to the $\mathrm{T}_{4}-\mathrm{RT}_{3} \mathrm{U}$ index (4).

\section{Results}

\section{Comparison of $T_{4} N$ with the $T_{4}-R T_{3} U$ ratio}

44 freshly drawn serum samples from patients with suspected thyroid disorders were subjected to determination of the $\mathrm{RT}_{3} \mathrm{U}$ ratio, $\mathrm{T}_{4}(\mathrm{D})$ and $\mathrm{T}_{4} \mathrm{~N}$ in Sephadex columns. All determinations were in duplicate. With each method, all tests were carried out in one day. $\mathrm{T}_{4} \mathrm{~N}$ values were plotted against $T_{4}-R T_{3} U$ ratio values.

Figure 1 shows the correlation between the two methods. The correlation was evident, the coefficient of correlation being 0.83 .

This correlation proved to be better than in the comparison of $T_{4} \mathrm{~N}$ with $T_{4} D$ or with the $R T_{3} U$ ratio alone, indicating that the $\mathrm{T}_{4} \mathrm{~N}$ determination is a comprise for both the $T_{3}$ binding properties in the sera under study.

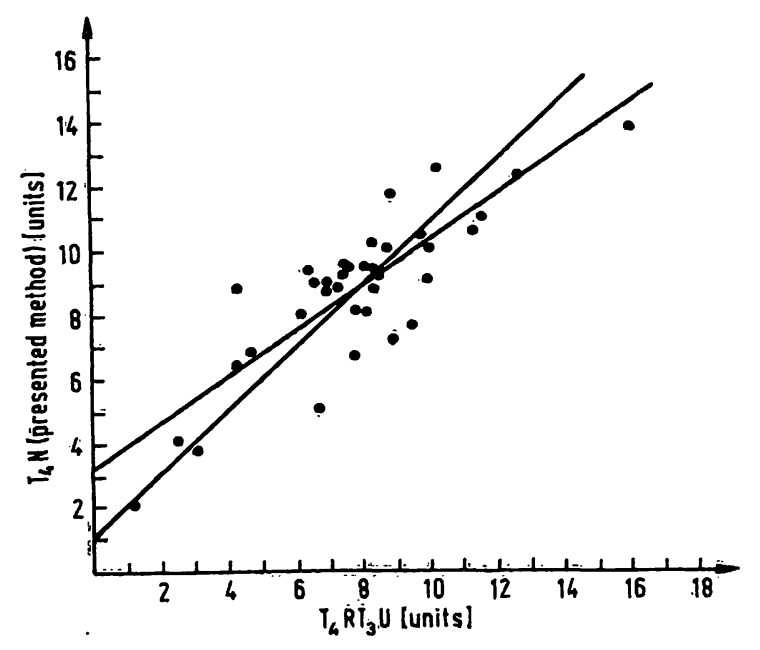

Fig. 1. Comparison between $\bar{T}_{4} \mathrm{~N}$ by Sephadex column and $\mathrm{T}_{4}-\mathrm{RT}_{3} \mathrm{U}$ index in 44 human sera; $\mathrm{r}=0.83 ; \mathrm{y}=1.02 \mathrm{x}$ $+0.9 ; x=1.42 y-4.8$.

\section{Comparison of $\mathrm{T}_{4} \mathrm{~N}$ with $\mathrm{T}_{4} \mathrm{~N}$ Quantisorb}

The Quantisorb kit of Abbott, which employs a numeration for $\mathrm{T}_{4} \mathrm{~N}$ units corresponding to the methods described above, was used as a reference method for the $\mathrm{T}_{4} \mathrm{~N}$ determination.

44 other freshly drawn serum samples from patients with suspected thyroid disorders were measured for $\mathrm{T}_{4} \mathrm{~N}$ by the Sephadex column method and by $\mathrm{T}_{4} \mathrm{~N}$ determination with the Quantisorb kit. All determinations were in duplicate. With each method, all tests were carried out in one day. Figure 2 shows the correlation between the two methods, the correlation coefficient was 0.93 .

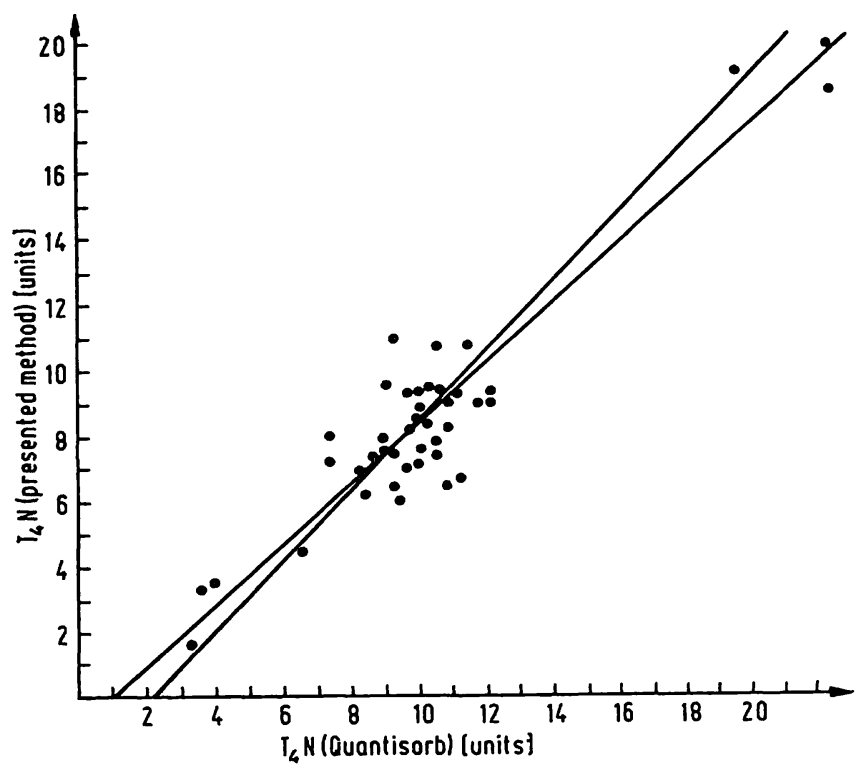

Fig. 2. Comparison between $T_{4} \mathrm{~N}$ by Sephadex column and $T_{4} \mathrm{~N}$ Quantisorb in 44 human sera; $r=0.93 ; y=0.93 x-0.9$; $x=0.93 y+2.2$.

\section{Reproducibility}

The intra-assay variation was between $\mathrm{CV}=5 \%$ and $\mathrm{CV}=6 \%$.

The interassay (day-to-day) variation was determined by running seven reference sera of low, medium and high $\mathrm{T}_{4} \mathrm{~N}$ levels together with other patients' sera on seven separate days. Table 1 shows the $\mathrm{T}_{4} \mathrm{~N}$ values of the

Tab. 1. $\mathrm{T}_{4} \mathrm{~N}$ day-to-day variation of reference sera tested on seven separate days.

\begin{tabular}{lcll}
\hline $\begin{array}{l}\text { Reference } \\
\text { serum }\end{array}$ & $\begin{array}{l}\text { Mean } \mathrm{T}_{\mathbf{4}} \mathrm{N} \\
\text { [Units] }\end{array}$ & S.D. & $\begin{array}{l}\text { CV } \\
{[\%]}\end{array}$ \\
\hline 1 & 5.4 & 0.4 & 7.4 \\
2 & 9.0 & 0.4 & 4.4 \\
3 & 17.1 & 1.0 & 5.8 \\
4 & 8.9 & 0.6 & 6.7 \\
5 & 9.4 & 0.7 & 7.4 \\
6 & 10.9 & 0.9 & 8.3 \\
7 & 24.5 & 1.1 & 4.5 \\
\hline
\end{tabular}


reference sera and the respective standard deviations and $\mathrm{CV}$ values for the day-to-day variation for single determinations.

The mean interassay variation of all seven sera was approximately $\mathrm{CV}=6 \%$.

\section{Discussion}

The method described gives the same parameter as the product of $T_{3}$ uptake and $T_{4}$, which is an estimate of free thyroxine. However, the product is an indirectly obtained figure that is subject to errors from both assays. Therefore a single test for evaluating thyroid metabolic status, making use of an appropriate Sephadex column system, offers a better opportunity for a reliable and reproducible assay of thyroid function.

The satisfactory correlation with the $\mathrm{T}_{4}-\mathrm{RT}_{3} \mathrm{U}$ index and the favourable figures for intra-assay variation (CV between $5 \%$ and $6 \%)$ and interassay variation $(\mathrm{CV}=6 \%)$ give strong experimental support to this assumption. The Sephadex column system has already proved its reliability in thyroxine testing $(7,9,10)$. The strong advantages are the easy handling procedure and the absence of centrifugation; the limiting time factor is the elution velocity of the buffers through the Sephadex columns. Excluding counting time, it takes only 30-45 minutes to process 10 samples.

The second advantage of the Sephadex column system above other commercially available $\mathrm{T}_{4} \mathrm{~N}$ methods is the relative insensitivity to interfering lipids which are present in different quantities in patients' sera. It is known that nonesterified fatty acids inhibit the binding of radioactive thyroxine by thyroxine binding globulin. This inhibition leads to falsely elevated estimates of serum $\mathrm{T}_{4}$ by competitive protein binding analysis. Such methods for thyroxine which utilize direct analysis of alcoholic extracts of serum without prior solvent evaporation are especially susceptibel to interference by non-esterified fatty acids $(11,12)$.

In the method under study the liberation of thyroxine from its serum proteins is complete, due to the alkaline denaturation step at the beginning of the test. The columns are washed consecutively with buffer to shift the $\mathrm{pH}$ of the columns to 8.6 and to wash out any free

${ }^{125} \mathrm{I}$ and serum proteins, including interfering substances such as lipids, before the real competitive binding stage starts. The test is therefore rather insensitive to the presence of free ${ }^{125} \mathrm{I}$ in the $T_{4}$ tracer and to the presence of lipids and other interfering substances, such as salicylates in the sample (13).

A disadvantage of the system under study could be the relative high price of Sephadex columns, but the Sephadex columns can be easily regenerated by removing residual $\mathrm{T}_{4}$ tracer by serum elution, so that the Sephadex columns are rẹusable (10).

\section{Acknowledgements}

We thank Marian van Baar, Astrid van 't Riet and Ria Stokman for their skillful technical assistance. We are grateful to Dr. $A . F$. $M$. Roijers and Mr. P. W. Walton for reading the manuscript.

\section{References}

1. Abreau, C. M., Azizi, F., Vagenakis, A. G., Ingbar, S. H. \& Braverman, L. E. (1973), J. Nucl. Medicine 14, 159-163.

2. Howorth, P. J. N. \& Ward, R. L. (1972), J. Clin. Pathol. 25, 259-263.

3. Ashkar, F. S. \& Bezjian, A. A. (1972), J. Am. Med. Ass. $221,1483-1485$.

4. Solomon, D. H., Benotti, J., Groot, J. L. de, Greer, M. A., Pileggi, V. J., Pittman, J. A., Robbins, J., Selenkov, H. A., Sterling, K. \& Volpe, R. (1972), J. Clin. Endocrinol. 34, 884-890.

5. Braverman, L. E., Vagenakis, A. G., Foster, A. E. \& Ingbar, S. H. (1971), J. Clin. Endocrinol. 32, 497-507.

6. Thorson, S. C., Mincey, E. K., McIntosh, H. W. \& Morrison, R. T. (1972), Br. Med. J. 67-71.

7. Alexander, N. M. \& Jennings, J. F. (1974), Clin. Chem. 20, 553-559.

8. Goedemans, W. Th., Bartels, P. C. \& Roijers, A. F. M. (1977), Clin. Chem. 23, 2324-2328.

9. Bartels, P. C., Goedemans, W. Th. \& Roijers, A. F. M. (1977), Clin. Chim. Acta 81, 63-73.

10. Alexander, N. M. (1976), Clin. Chim. Acta 69, 293-298.

11. Shaw, W., Hubert, I. L., Powell, M. K. \& Spierto, F. W. (1976), Clin. Chem. 22, 673-678.

12. Bastomsky, C. H., McQuaid, M. P. \& Greenidge, M. E. (1977), Clin. Chim. Acta 75, 475-481.

13. Goedemans, W. Th., Eilermann, L. J. M. \& Hilvers, A. G. (1977), $L A B$, in press
W. Th. Goedemans

Cyclotron and Isotope Laboratories

Petten, The Netherlands 